JOURNAL

of Health Inequalities

\title{
Welcome adresses from Professor Aurelijus Veryga, Member of Parliament, former Minister of Health of Lithuania
}

\author{
Aurelijus Veryga \\ Member of Parliament (Seimas) of the Republic of Lithuania
}

ADDRESS FOR CORRESPONDENCE : Prof. Aurelijus Veryga, Member of Parliament (Seimas) of the Republic of Lithuania, e-mail: Aurelijus.Veryga@|rs.It

Thank you Professor and good morning everyone, friends and colleagues. Let me thank you for the invitation to take part in this Calisia Conference. It is a great pleasure for me to see professors like Professor Witold Zatoński, with whom I was growing up as a tobacco control activist and from whom I was learning how to make public health policy. I remember that Professor 25 years ago was calling me a tobacco control baby. I wonder how many of you know about the regional tobacco control conference 25 years ago in Poland, which began to turn my professional career into public service. I am very thankful to the professors that at that time were working and doing a tremendous job, demonstrating not just to Polish society but to the international society that tobacco control can be science and evidence based. Thank you very much Professor Witold for what you have done not just for Poland, but for international society.

Looking at the program for this conference, I really liked the focus on alcohol and tobacco. The tobacco smoking epidemic is not over yet, it is just getting a new face. What is happening now is that the tobacco industry is trying to use doctors and researchers to speak on their behalf, and the tactic is exactly the same as that used by them years ago. I remember the optimism of colleagues about the Framework Convention on Tobacco Control, and we were actually talking about tobacco endgame. The COVID pandemic itself brought new challenges. I'm talking about the health challenges, the challenges on mental health facing children and adults at the same time. The challenges relate to a possible increase in alcohol consumption that was for example noticed by Swedish experts and researchers, and today you will have an opportunity to discuss the possibilities to meet those challenges or to reduce the possible risks. You have a brilliant expert I see on my screen, Professor Jurgen Rehm, who will talk about that later on. I wish you a very good conference and thank you once again for inviting me. I am so happy to see, even if it's only on the screen, but still a very big number of participants and I'm sending you the best greetings from Lithuania.

Key words: Calisia conference, alcohol, tobacco control.

\section{DISCLOSURE}

The author reports no conflict of interest. 